protsesi fizychnoho vykhovannia (teoretyko-metodychnyi aspekt): monohrafiia [Formation of valeological competence of future teachers in the process of physical education (theoretical and methodological aspect)]. (Ed.). R. S. Hurevych. Vinnytsia, 388 p. [in Ukrainian].

5. Matviienko, O. V. \& Moroz, D. V. (2018). Tsinnisne stavlennia do zdorovia yak pedahohichna katehoriia [Value attitude to health as a pedagogical aspect]. Молодий вчений. No. 1(1).pp. 348-353. [in Ukrainian].

6. Nadolnyi, I. F. (2015). Svitohliad - kliuchova problema piznannia ta diialnosti liudyny [Worldview - the key problem of human cognition and activity]. Вісник Начіональної академії державного управління при Президентові України. Серія : Філософія. №. 4. pp. 50-54. [in Ukrainian].

7. Filosofskyi entsyklopedychnyi slovnyk (2002).
[Philosophical encyclopedic dictionary].(Ed.). V. I. Shynkaruk et al. Kyiv, 742 p. [in Ukrainian].

8. Khairulina, Yu. O. (2011). Svitohliadna kultura osobystosti : strukturno-funktsionalnyi analiz : monohrafiia [Person's worldview culture-structural and functional analysis]. Ministry of Education and Science, Youth and Sports of Ukraine. Nat. Mykhaylo Drahomanov Ped. University. 235 p. [in Ukrainian]

9. Shcherbak, I. M. \& Drozhyk, L. V. (2019). Pidhotovka maibutnikh uchyteliv do stvorennia ekolohovaleolohichnoho osvitnoho seredovyshcha yak osnovy zdoroviazberezhennia uchniv [Preparing future teachers for an ecological and valeological educational environment as a basis for student health preservation]. No. 3 (170). Youth \& market: monthly scientific-pedagogical journal. Drohobych, pp. 137-140. [in Ukrainian].

Стаття надійшла до редакції 30.10.2020

УДК 378.016-051:793.3

DOI:

Віра Максименко, аспірант, викладач кафедри музичної педагогіки та хореографії Ніжинського державного університету імені Миколи Гоголя

\title{
ОСОБЛИВОСТІ ФОРМУВАННЯ ХУДОЖНЬО-ТВОРЧОГО ДОСВІДУ В СИСТЕМІ ФАХОВОЇ ПІДГОТОВКИ МАЙБУТНЬОГО ВЧИТЕЛЯ ХОРЕОГРАФІЇ
}

У статті досліджуються особливості формування художньо-творчого досвіду в системі фахової підготовки майбутніх учителів-хореографів. Зазначається, щуо на сучасному розвитку мистецької освіти та оновлення ї̈ змістової сторони особливої уваги заслуговують питання щуодо переосмислення суспільного призначення професї вчителя хореографії, оскільки саме він здатний творчо впроваджувати сочіальнозначущуі новачії $і$ мобільно реагувати на культурні вимоги часу. Урахування цих особливостей вимагає від майбутнього спеціаліста хореографії особливої уваги до його фахової підготовки, а також особистісних якостей, цо формуються у процесі навчання.

Таку роботу дочиільно здійснювати у двох аспектах: по-перие, як стійкого утворення, тобто досвіду - результату, який передбачає становлення й розвиток його основних складових; по-друге, як проиесуального вияву, в якому великого значення набуває урахування необхідних умов, ияо забезпечують ефективність изього прочесу.

Ключові слова: фахова підготовка; хореографічна діяльність; методика викладання; художньотворчий досвід; творчий потенціал; вчитель-хореограф.

תim. 5.

Vira Maksymenko, Postgraduate Student, Lecturer of the Music Pedagogy and Choreography Department Nizhyn Mykola Hohol State Pedagogicul University

\section{THE PECULIARITIES OF FORMATION OFARTISTICAND CREATIVE EXPERIENCE INTHE SYSTEMOF PROFESSIONAL TRAINING OFTHE FUTURE CHOREOGRAPHY TEACHER}

The article examines the peculiarities of the formation of artistic and creative experience in the system of professional training of the future teachers-choreographers. It is pointed out that the issues of rethinking the social function of the profession of choreography teacher deserve particular attention in the modern development of art education and updating its content, because it is able to implement the socially-significant innovations creatively and respond mobile to the cultural demands of time. Taking into consideration these features requires from the future choreography specialist special attention to his professional training, as well as personal qualities that are formed in the learning process.

Such work should be realized in two aspects: firstly, as a resistant formation, namely experience - a result that involves the formation and development of its main components; secondly, as a procedural demonstration, in which it is important to take into account the necessary conditions to provide the effectiveness of this process.

The specifics of formation of general pedagogical and special skills of students-choreographers in the system 
of professional training, realization of potential in the field of art education are revealed in detail, which provides all-in-one view on the problem of training future specialists as for artistic and creative activity and also for methodical education. The peculiarity of the formation of artistic and creative experience of the future choreography teacher in the process of professional training is due to the creative essence of choreographic art and choreographic learning, the variety of forms of artistic and educational and choreographic and performing activities of students, which became a catalyst for the quality of education in higher education institution.

Keywords: professional training; choreographic activity; teaching methods; an artistic and creative experience; creative potential; a teacher-choreographer.

П остановка проблеми. Перебудова національної освітньої галузі вимагає від закладів вищої освіти підготовки кваліфікованих, креативних фахівців, здатних до постійного професійного розвитку, творчого мислення та самовдосконалення. Національна доктрина розвитку освіти Україні у ХXI ст. (2002 р.) передбачає створення умов для формування творчих здібностей молодого покоління, для творчого самовизначення й самореалізації. У контексті цих завдань особливого значення набуває проблема формування художньотворчого досвіду в системі фахової підготовки майбутнього вчителя хореографії. Не викликає заперечень, що обізнаність і здатність творчо мислити та діяти у сфері науки і культури мають формуватися у процесі фахової підготовки. Підготовка спеціаліста в галузі хореографічного мистецтва вимагає особливої уваги як до його фахової підготовки так і формування особистісних якостей.

3 урахуванням цих положень уважаємо доцільним розглядати проблему формування художньо-творчого досвіду в процесі фахового навчання майбутніх вчителів хореографії у двох аспектах: по-перше, як стійке утворення, тобто досвід - результат, який передбачає становлення й розвиток його основних складових; по-друге, як процесуальний вияв, в якому великого значення набуває урахування необхідних умов, що забезпечують ефективність цього процесу. Дотримуючись логіки дослідження, розглянемо можливості формування художньо-творчого досвіду майбутнього вчителя хореографії у межах мистецької системи освіти України.

Аналіз наукових досліджень доводить, що вітчизняними науковцями здебільшого піднімалися такі проблеми: формування професійних умінь майбутніх учителів хореографії (Л. Андрощук, О.Бурля,С.Забредовський,О.Мартиненко,О.Таранцева та ін.); формування індивідуального стилю діяльності майбутнього вчителя хореографії (Л. Андрощук); формування художньо-естетичного досвіду майбутніх учителів хореографії(Т. Сердюк); формування творчого потенціалу майбутнього вчителя хореографії (С. Куценко); формування педагогічних переконань майбутніх учителів музики і хореографії (Ю. Ростовська); українська народна хореографічна культура XX ст. (С. Легка); формування художньо-ментального досвіду майбутніх учителів музичного мистецтва та хореографії (О. Реброва); основи професійної творчості майбутніх хореографів (О. Бережна); професійно-творче становлення особистості студента-хореографа (М. Юр'єва); формування балетмейстерських умінь майбутніх учителів хореографії (О. Пархоменко); організація навчання хореографії дітей молодшого шкільного віку у закладах позашкільної освіти України (друга половина XX ст.) (К. Зозуля); трансформація української народної хореографії та її концептуалізація в театрі танцю Павла Вірського (В. Литвиненка) тощо.

Однак незважаючи на значну кількість наукових досліджень, проблема формування художньо-творчого досвіду в системі фахової підготовки майбутнього вчителя хореографії розглядається лише частково, що пов'язується зі складністю і багатогранністю означеного феномена.

Метою статті $є$ розкриття особливостей формування художньо-творчого досвіду майбутніх фахівців у галузі хореографічної освіти.

Виклад основного матеріалу. Специфіка фахової підготовки майбутніх учителів хореографії визначається тим, що технології формування професійної майстерності і розвитку хореографічних здібностей тісно пов'язані з професійним самовираженням та особистісним покликанням в галузі хореографічної діяльності. Вона спрямовується не лише на професійне оволодіння технічною майстерністю, а й на засвоєння методик викладання дисциплін хореографічного циклу, формування загальнопедагогічних та спеціальних умінь.

Відтак система професійного навчання студентів-хореографів закладу вищої педагогічної освіти $є$ досить складною і довготривалою. Під час навчання у студентів формуються особливі знання та уміння, які змістовно збагачуються на шляху розв'язання різноманітних завдань професійної діяльності. Вміння виражати індивідуальні почуття дають змогу розвивати і реалізувати в процесі фахової підготовки 


\section{ОСОБЛИВОСТІ ФОРМУВАННЯ ХУДОЖНЬО-ТВОРЧОГО ДОСВІДУ В СИСТЕМІ ФАХОВОЇ ПІДГОТОВКИ МАЙБУТНЬОГО ВЧИТЕЛЯ ХОРЕОГРАФІЇ}

художньо-творчу індивідуальність, накопичувати у цій галузі власний безцінний досвід.

У педагогічній науці поняття “досвід” зазвичай вживається із позиції закріплення певного матеріалу або практичного застосування знань, умінь, навичок. Розвиток особистості зумовлюється її досвідом, він є не тільки передумовою певної діяльності, але і $1 і ̈$ результатом. Його набуття пов'язується із повторенням діяльності, що здійснюється на основі спеціально організованих впливів. Застосування досвіду у навчанні дає можливість учням самим пізнавати матеріал шляхом особистої участі у реальних ситуаціях. На таку позицію звертав увагу Дж. Дьюї, який писав: “Відбиток, який залишає власне, особисте усвідомлення, формує позицію людини набагато глибше, ніж привнесене ззовні правило про те, як має бути" $[4,187]$.

У галузі хореографічного мистецтва існують загальні закономірності становлення фахівця від початку професійної діяльності до самостійної творчої праці, зумовлені приналежністю хореографії до сценічних видів мистецтва.

Передовсім зазначимо, що танець як найстаріший вид мистецтва з'явився ще на етапі генетичної і культурної еволюції людства і розвивався завдяки таким засобам, як мелодія, ритм, симетрія та рисунок. Він належить до складних видів мистецтва, оскільки інтегрує у собі: художній рух (кінестетику, міміку й пантоміміку); музику (вокальний або інструментальний; мелодичний або ритмічний супровід); елементи образотворчого мистецтва (композиція, орнаментальний малюнок танцю, костюми, маски, декорації) та театралізації (розподіл танцювальних партій; сюжетна лінія й драматургія тощо). При цьому композиція надає танцювальному твору сутнісну завершеність, формуючи співвідношення елементів його змісту та їх розташування.

Одразу ж зауважимо, що основним виразним засобом танцю є людське тіло, яке має природну пластику. В хореографії іï розглядають як загальну якість всього організму. Під час виконання танцю зовнішній, тілесний, образ виконавця, поданий у русі, значною мірою відображає сутність художнього образу. Саме завдяки пластиці рухи тіла набувають безмежних властивостей для удосконалення грації та ліній. Це твердження грунтується на особливості, яку в хореографії називають “пластична форма душі", тому що пластика стає справжнім вираженням почуттів [3].

Оскільки ритм є одним з основних компонентів танцю, він стає засобом вираження емоцій шляхом постійної зміни рухів, підпорядкованих певному ритму. У зв'язку з цим А. Хаскел зазначав: “Танець - це засіб вираження емоцій шляхом постійної зміни рухів, підпорядкованих певному ритму" [3], а реформатор балетного мистецтва М. Фокін підкреслював: “Будь-який рух у художньому танці є вдосконаленням, розвитком природного руху відповідно до характеру, який цей танець повинен виявити. Жоден відступ від натурального руху не повинен бути невиправданим" [7, 424].

На думку італійського балетмейстера К. Блазіса, музика повинна описувати дійових осіб та їхні пристрасті, уточнюючи і завершуючи їхні портрети. Сенс мелодії у музиці повинен змінюватися відповідно до сюжету. Необхідно, щоб досконала аналогія була між тим, що вражає зір та слух $[1,161]$.

Більш широко трактує це поняття К. Василенко. За його переконанням, хореографічний образ $є$ естетичною категорією, під якою розуміють конкретні чи узагальнені сцени життя, природи, створені балетмейстером за допомогою вигадки, асоціативного бачення [2, 131]. Він уважає, що “танець починається 3 музики, виростає 3 неї”, адже супроводжуючи кожен танцювальний рух, мелодія допомагає розкрити образи танцю $[2,248]$.

Крім того, танець може виконувати різні функції-гедоністичну, комунікативну, розвивальну, кожна $з$ яких несе в собі індивідуальний відтінок і народжує певні типи “танцювальної експресії” [5].

Отже, танець 3 музикою можуть співіснувати тільки в синтезі, і тільки в цьому випадку народжується мистецький твір.

3 цієї точки зору мистецтво танцю охоплюється широким поняттям “хореографічна культура”, яке розглядається як невід’ємна частина світової художньої культури, залежної від звичок та уявлень конкретної епохи. Необхідними передумовами для іiі розвитку є емоційно-чуттєве ставлення до явищ довкілля щодо сприйняття світу, особиста значущість художньої творчості (мотивація), наявність розвиненого художнього бачення, образної пам'яті, творчого мислення, естетичного почуття, здатність до емпатії, що загалом характеризує художньо-творчу діяльність.

Сучасною педагогікою мистецтва розвиваються окремі аспекти цієї ідеї, яка є важливою для нас у контексті пошуку конкретних шляхів фахової підготовки майбутнього вчителя хореографії. Так, наприклад, підтвердження того, що підготовка вчителя хореографії передбачає інтегративність опанування ним предметів мистецькоестетичного та культурологічного циклу на основі 
взаємозв'язку та синтезу споріднених видів мистецтва, знаходимо в дослідженнях О. Олексюк, О. Отич, Г. Падалки, Л. Масол, Н. Миропольської, О. Ростовського, О. Рудницької,О. Федій,О.Щолокової, О. Шевнюк, Г. Шевченко та ін., які досліджують можливості інтеграції мистецтв у процесі пізнання і творчої діяльності як джерела гармонізації розвитку педагога.

Вони зазначають, що під час опанування мистецтва у всьому його розмаїтті народжуються естетичні цінності, за допомогою яких поповнюється потенціал професійної майстерності вчителяхореографа, збагачується його жанрова палітра. Саме тому дослідження закономірностей і принципів функціонування, розвитку художньої творчості, iї соціального буття постає важливим питанням розвитку творчого потенціалу студентів-хореографів як підгрунтя їх художньотворчого досвіду.

Серед різних факторів, які впливають на становлення та реалізацію художньо-творчого потенціалу фахівця у галузі мистецької освіти, вчені виокремлюють задатки (вроджену якість), соціальне середовище (зовнішні умови впливу) $\mathrm{i}$ особистісну творчу активність. Екстраполюючи цю позицію на хореографічну галузь, зазначимо, що ці фактори характеризують учителя хореографії як унікальну особистість, яка володіє потенціалом безперервного саморозвитку, самореалізації і самовираження. Тобто, актуальний стан художньо-творчого потенціалу майбутніх фахівців залежить від внутрішніх зусиль студентів заради культивування у собі творчої потенції.

Важливим висновком для педагогіки мистецтва стала позиція вчених стосовно того, що новизна, яка виникає внаслідок творчої діяльності, може мати як об'єктивний так i суб'єктивний характер. Об'єктивна цінність визначається за такими результатами творчості, в яких розкриваються раніше невідомі закономірності оточуючого світу, встановлюються і пояснюються зв'язки між явищами, котрі раніше вважалися не зв'язаними між собою. Суб'єктивна цінність результатів творчої діяльності стає важливою тоді, коли результат не має об'єктивної новизни, а є новим для особистості, яка його вперше створила. Уточнює цю позицію О. МєлікПашаєв. Він розглядає творчість як “результат потреби у вираженні свого внутрішнього світу" $[6,79]$. При цьому діяльність людини є творчою, навіть якщо іiї результат має тільки суб'єктивну новизну, тобто є новим для цієї людини.

У галузі хореографічного мистецтва існують такі професійні спеціальності: хореограф- виконавець, хореограф-балетмейстер, хореографпедагог, балетознавець або хореолог (історик, теоретик, критик). Отже, людина, яка присвятила себе танцювальному мистецтву, формує свій спосіб життя відповідно до вимог цього мистецтва. Це дозволяє їй напрацювати такі важливі якості, як цілеспрямованість, працьовитість і оптимізм, уміння аналізувати й робити висновки, корегувати власні помилки, виховувати у собі силу волі.

Художньо-творчий потенціал педагогахореографа синтезує в собі різні види творчості, які є водночас його специфічними особливостями, оскільки поєднує хореографічну, музикознавчу, методичну, педагогічну і дослідницьку роботу. Під час хореографічного навчання у педагогічному університеті студенту необхідно розвинути свій художньо-творчий і професійний потенціал, інтегруючи професійні і фахові знання, уміння й навички.

3 урахуванням визначених вище позицій розглянемо особливості художньо-творчого потенціалу майбутніх фахівців у галузі хореографічної освіти.

Сучасний досвід викладання хореографічних дисциплін доводить, що для оновлення змісту хореографічної освіти перевага має надаватися не стільки обсягу фахових знань, умінь і навичок, скільки їх глибині, системності, усвідомленому сприйманню, гнучкості й достатності для подальшої професійної діяльності студентів.

Відповідна професійно-змістовна підготовка студентів буде, на нашу думку, ефективною за умови досягнення органічної єдності предметних циклів спеціальності “Хореографія”, ̈іх комплексного взаємозв'язку й взаємопроникнення, тобто застосування внутрішньо предметної та міжпредметної інтеграції. Для цього вважаємо доцільним включати до навчальних програм теми, які розкривали б художньо-творчі особливості роботи хореографа в різних галузях хореографічної діяльності.

Натомість дослідниця В. Шеремета вважає, що в основі логіки і змісту спеціальної підготовки фахівців має бути оволодіння не тільки загальними принципами створення хореографічного твору, а й специфічними педагогічними методами, оскільки хореограф є не тільки творцем, але й учителем. Головним же в підготовці спеціалістівхореографів, на думку автора, стає розкриття індивідуальності, виховання хореографа-творця 3 високим інтелектом, абстрактним і парадоксальним мисленням, можливостями виражати внутрішній світ через індивідуальну форму руху, а також оволодіння 


\section{ОСОБЛИВОСТІ ФОРМУВАННЯ ХУДОЖНЬО-ТВОРЧОГО ДОСВІДУ В СИСТЕМІ ФАХОВОӤ ПІДГОТОВКИ МАЙБУТНЬОГО ВЧИТЕЛЯ ХОРЕОГРАФІЇ}

педагогічними прийомами передачі своїх ідей та задумів учням [8, 208-209].

Водночас глибокі фахові знання можна набути тільки на основі розуміння загальних базових психологічних законів творчого самовираження, усвідомлення своїх психічних можливостей, серед яких найбільш важливими є такі:

- розуміння себе і сенсу своєї творчості у процесі хореографічно-освітньої діяльності;

- вміння бачити у навколишньому світі незвичайне, цікаве, дивовижне, надавати нового смислу знайомим явищам, оригінально виражати задумане, вірити у свої творчі сили;

- розвитоктворчих хореографічних компетентностей шляхом упровадження спеціальних знань;

- мотивація майбутніх учителів хореографії до мистецько-педагогічної діяльності, яка забезпечує послідовне становлення їх творчої індивідуальності; упровадження інноваційних форм і методів навчання.

Необхідно також додати, що розширенню художньо-естетичного розвитку студентів та підвищенню ефективності освітнього процесу значною мірою сприяє використання комп'ютерних технологій на заняттях з фахових дисциплін, за допомогою яких вони можуть переглянути відеоматеріали виступів професійних хореографічних колективів, відвідувати майстеркласи провідних фахівців у галузі танцювального мистецтва тощо.

Отже, сучасна фахова підготовка майбутнього вчителя хореографії передбачає формування знань, умінь, навичок, які спираються на естетичні уподобання, психологічні ресурси і резерви студентів. Безперервне накопичення способів орієнтації в процесі художньо-освітньої діяльності зумовлює появу нових фахових здібностей i можливостей. При цьому переживання, які виникають у майбутнього фахівця, стають рушійною силою активності, спрямованої на розширення власних художніх потенцій.

На підставі окреслених положень художньотворчий досвід учителя хореографії можна представити як особистісне утворення, яке $\epsilon$ результатом інтеграції фахових знань та умінь на вищому рівні хореографічної діяльності, сприяє розвитку творчого потенціалу та забезпечує самостійну продуктивно-пошукову активність для розв'язання завдань хореографічної освіти учнівської молоді.

Необхідними передумовами для його розвитку $\epsilon$ емоційно-чуттєве ставлення до явищ навколишньої дійсності щодо сприйняття світу, особиста значущість художньої творчості (мотивація), наявність розвиненого художнього бачення, образної пам'яті, творчого мислення, естетичного почуття, здатність до емпатії. Усі ці якості необхідні для розвитку особистості в процесі хореографічного навчання у педагогічному університеті, оскільки вони є результатом поєднання духовних (інтелектуальних, емоційних, вольових) і практичних можливостей майбутнього фахівця у процесі творчого перетворення навколишньої дійсності в художній образ.

Висновки. Враховуючи вищезазначене, вважаємо, що формування художньо-творчого досвіду $\epsilon$ обов'язковою умовою фахової підготовки педагога-хореографа, оскільки творчість - це постійний і природний супутник формування особистості. Під нею розуміють діяльність, результатом якої є створення індивідуально нового, неповторного, оригінального. Формування художньо-творчого досвіду студентів-хореографів в освітньому процесі передбачає їх залучення до творчої діяльності через мистецтво танцю. У контексті нашого дослідження формування художньо-творчого досвіду майбутніх педагогів-хореографів передбачає:

1) самостійність та ініціативу у підході до вивчення історико-теоретичних, художньоінтерпретаційних, і методичних проблем, набуття фахових виконавських умінь і навичок. Згідно 3 освітнім стандартом, вчителі-хореографи повинні мати уявлення про творчі здобутки видатних представників хореографічного мистецтва, різних виконавських шкіл, розвиток художніх стилів й основних жанрів та форм тощо, а також уміти передавати ці знання під час виконавськопедагогічної інтерпретації хореографічних творів;

2) розвиток фантазії та уявлень у виконавській і педагогічній навчальній діяльності. Вчительхореограф повинен володіти імпровізаційними навичками, розвиток яких зумовлений наявністю грунтовних фахових знань та інтуїції;

3) володіння вольовими якостями для втілення творчих задумів під час виконавськохореографічної діяльності, ефективне використання власного інтерпретаційного досвіду в нових умовах;

4) вміння оперувати сформованими уміннями і набутим обсягом теоретичної інформації й практичних навичок, використовувати нагромаджений досвід у процесі хореографічнопедагогічної діяльності;

5) виховання потреби в безперервному оновленні й збагаченні багажу образноінтерпретаційних знань, умінь і навичок відповідно до естетичних і педагогічних завдань, а також до 


\section{ОСОБЛИВОСТІ ФОРМУВАННЯ ХУДОЖНЬО-ТВОРЧОГО ДОСВІДУ В СИСТЕМІ ФАХОВОЇ ПІДГОТОВКИ МАЙБУТНЬОГО ВЧИТЕЛЯ ХОРЕОГРАФІІ}

виконавсько-хореографічного самовдосконалення та самоосвіти;

6) здатність до оцінювання власної виконавсько-хореографічної діяльності та їі результатів, до творчого застосування інтерпретаційних ідей;

7) розвиток внутрішньої установки на трансформацію фахового навчання 3 метою оптимізації позитивних впливів на учнівську молодь під час хореографічного навчання виховання.

Отже, особливості формування художньотворчого досвіду майбутніх учителів хореографії зумовлені творчою сутністю хореографічного мистецтва i хореографічного навчання, різноманітністю форм художньо-освітньої та хореографічно-виконавської діяльності студентів, яка стимулює прояви мистецько-педагогічної свободи й суб'єктності, реалізації інтелектуальних, професійних здібностей, умінь та навичок, свого фахового “Я” і власного художньо-творчого потенціалу.

\section{ЛІТЕРАТУРА}

1. Блазис К. Классики хореографии / под. ред. Е. И. Чеснокова. Москва; Ленинград, 1937.356 с.

2. Василенко К. Ю. Український танець : підручник. Київ, 1997. 282 с.

3. Воронін Р. С. Философско-эстетические и художественные аспекты танцевального искусства (спортивный бальный танец, вторая половина XX века) : автореф. дис. ... канд. искусствоведения : 7217.00.09. Санкт-Петербург, $2007.25 \mathrm{c}$.

4. Дьюї Дж. Демократія і освіта. Київ, 2002. $252 \mathrm{c}$.

5. Материалы. Воспоминания. Статьи / сост. иавт. примеч. А. Нехендзи; предисл. Ю. Слонимского. Ленинград, 1971. 446 с. : ил.; 20 л. ил.

6. Мелик-Пашаев А. А., Новлянская 3. Н. Ступеньки к творчеству. Москва, 1987. 144 с.
7. Фокин М.М. Против течения. Москва; Ленинград, 1962.638 с.

8. Шеремета, В. І. Освітньо-професійна програма підготовки педагогів-хореографів та ії практична реалізація. Науковий вісник Уэсгородського університету: Серія: Педагогіка. Сочіальна робота, 2011. С. 207-209.

\section{REFERENCES}

1. Blazys, K. (1937). Klassiki khoreografii [Choreography classics]. (Ed.). Ye. I. Chesnokov. Moscov; Leningrad, 365 p. [in Russian].

2. Vasylenko, K. Yu. (1997). Ukrainskyi tanets [Ukrainian dance: a textbook]. Kyiv, 282 p. [in Ukrainian].

3. Voronin, R. Ye. (2007). Filosofsko-esteticheskie $i$ khudozhestvennye aspekty tantsevalnogo iskusstva (sportivnyy balnyy tanets, vtoraya polovina XX veka) [Philosophical, aesthetic and artistic aspects of dance art (sports ballroom dance, second half of the XX century)]. Extended abstract of candidate's thesis. Sankt-Peterburg, 25 p. [in Russian].

4. Diui, Dzh. (2002). Demokratiia i osvita [Democracy and education]. Kyiv, 252 p. [in Ukrainian].

5. Nekhendzy, A., \& Slonymskoy, Yu. (Eds.). (1971). Materialy. Vospominaniya. Stati [Materials. Memories. Articles]. Leningrad, 446 p. [in Russian].

6. Melyk-Pashaev, A. A., \& Novlianskaia, Z. N. (1987). Stupenki k tvorchestvu [Steps to creativity]. Moscov, 144 p. [in Russian].

7. Fokyn, M.M. (1962). Protiv techeniya [Against the stream]. Moscov; Leningrad, 638 p. [in Russian].

8. Sheremeta, V. I. (2011). Osvitno-profesiina prohrama pidhotovky pedahohiv-khoreohrafiv ta yii praktychna realizatsiia [The educational and professional training program for teachers of choreography and its practical implementation]. Scientific Bulletin of Uzhhorod University: Series: Pedagogy. Social work. pp.207-209. [in Ukrainian]

Стаття надійшла до редакції 30.10.2020

\section{G58080}

“Несқінченне прагнення бути қращим є обов'язком людини. Нூе вже саме по собі $\epsilon$ винагородою. Все інше в рукахБожих”.

Магадма Танді

індійсъқий державний і політичний діяч

“Учитель - це той же вчений, але в свойй особливій лабораторій, де він, всебічно вивчаючи учнів, невпинно творить, щоденно веде пошуки найдосконаліших методів проектування доль $і$ душ людсъких".

Борис Татон

уқрайнський науковеиь у галузі зварювальних проиесів, металургіӥ і технологій металів G58080ल2058080 